\title{
Syntheses, structures, and properties of phenyltrihydroborate complexes of zirconocene and titanocene
}

\author{
Fu-Chen Liu ${ }^{\text {a,* }}$, Jung-Hua Chen ${ }^{\text {a }}$, Shou-Chon Chen ${ }^{\text {a }}$, Ko-Yu Chen ${ }^{\text {a }}$, \\ Gene-Hsian Lee ${ }^{b}$, Shie-Ming Peng ${ }^{b}$ \\ a Department of Chemistry, National Dong Hwa University, Hualien 974, Taiwan, ROC \\ ${ }^{\mathrm{b}}$ Department of Chemistry, National Taiwan University, Taipai 106, Taiwan, ROC
}

Received 17 May 2004; accepted 14 September 2004

Available online 14 October 2004

\begin{abstract}
The phenyltrihydroborate complexes, $\mathrm{Cp}_{2} \mathrm{ZrCl}\left\{(\mu-\mathrm{H})_{2} \mathrm{BHPh}\right\}, \mathbf{1}$, and $\mathrm{Cp}_{2} \mathrm{Zr}\left\{(\mu-\mathrm{H})_{2} \mathrm{BHPh}\right\}_{2} \cdot(1 / 2$ toluene), 2, were prepared from the reactions of $\mathrm{Cp}_{2} \mathrm{ZrCl}_{2}$ with one and two moles of $\mathrm{LiBH}_{3} \mathrm{Ph}$. The $\mathrm{Zr}-\mathrm{H}-\mathrm{B}$ bonds in 2 are stable under vacuum at 100 ${ }^{\circ} \mathrm{C}$ for hours without significant decomposition. An inductive effect has been proposed for this strong interaction. This hydrogen bridge bond can be broken upon reacting with the Lewis base $\mathrm{N}\left(\mathrm{C}_{2} \mathrm{H}_{5}\right)_{3}$ to produce $\left(\mathrm{C}_{2} \mathrm{H}_{5}\right)_{3} \mathrm{~N} \cdot \mathrm{BH}_{2} \mathrm{Ph}$ and the zirconium hydride compound $\mathrm{Cp}_{2} \mathrm{ZrH}\left\{(\mu-\mathrm{H})_{2} \mathrm{BHPh}\right\}$, 3. Compound 3 also can be prepared from the reaction of $\mathrm{Cp}_{2} \mathrm{ZrHCl}_{\mathrm{Hith}} \mathrm{LiBH} \mathrm{Ph} \mathrm{The}$ reaction of 1 with the Lewis acid $\mathrm{B}\left(\mathrm{C}_{6} \mathrm{~F}_{5}\right)_{3}$ is solvent dependent, the metathesis product $\mathrm{Cp}_{2} \mathrm{ZrCl}\left\{(\mu-\mathrm{H})_{2} \mathrm{~B}\left(\mathrm{C}_{6} \mathrm{~F}_{5}\right)_{2}\right\}, \mathbf{4}$, was formed in the toluene solution, whereas the ionic complex $\left[\mathrm{Cp}_{2} \mathrm{ZrCl}\left(\mathrm{OEt}_{2}\right)\right]\left[\mathrm{HB}\left(\mathrm{C}_{6} \mathrm{~F}_{5}\right)_{3}\right]$, 5, was isolated from the ether solution. The reaction of titanocene dichloride, $\mathrm{Cp}_{2} \mathrm{TiCl}_{2}$, with $\mathrm{LiBH}_{3} \mathrm{Ph}$ produced a 17-electron, paramagnetic complex, $\mathrm{Cp} \mathrm{T}_{2} \mathrm{Ti}\left\{(\mu-\mathrm{H})_{2} \mathrm{BHPh}\right\}, \mathbf{6}$. Single crystal X-ray structures of $\mathbf{1}, \mathbf{2}, \mathbf{3}, \mathbf{4}, \mathbf{5}$, and $\mathbf{6}$ were also determined. A coplanar structure of the four bridge hydrogens in $\mathbf{2}$ was observed. (C) 2004 Elsevier B.V. All rights reserved.
\end{abstract}

Keywords: Phenyltrihydroborate; Organohydroborate; Hydroborate; Crystal structure; Zirconocene; Titanocene

\section{Introduction}

Many tetrahydroborate metal complexes have been studied extensively during the past 50 years [1], however, only a few examples of the organohydroborate metal complexes have been reported. While most of the known complexes are organodihydroborate compounds, the organotrihydroborate complexes are rare. To our knowledge, there are only several organotrihydroborate anions, including $\left[\mathrm{BH}_{3} \mathrm{CH}_{3}\right]^{-}[2],\left[\mathrm{BH}_{3} \mathrm{CO}_{2} \mathrm{R}\right]^{-}(\mathrm{R}=\mathrm{H}$, $\left.\mathrm{CH}_{3}, \mathrm{C}_{2} \mathrm{H}_{5}\right)$ [3], $\left[\mathrm{BH}_{3} \mathrm{CN}\right]^{-}$[4], and $\left[\mathrm{BH}_{3} \mathrm{C}\left(\mathrm{SiMe}_{3}\right)_{3}\right]^{-}$ [5], that have been used to prepare the corresponding complexes. However, only few complexes were prepared from the $\left[\mathrm{BH}_{3} \mathrm{CO}_{2} \mathrm{R}\right]^{-}\left(\mathrm{R}=\mathrm{H}, \mathrm{CH}_{3}, \mathrm{C}_{2} \mathrm{H}_{5}\right)$ or the

\footnotetext{
${ }^{*}$ Corresponding author. Tel.: +038633601; fax: +038633570

E-mail address: fcliu@mail.ndhu.tw (F.-C. Liu).
}

$\left[\mathrm{BH}_{3} \mathrm{C}\left(\mathrm{SiMe}_{3}\right)_{3}\right]^{-}$anions [3,5]. While many methyltrihydroborate, $\left[\mathrm{BH}_{3} \mathrm{CH}_{3}\right]^{-}$, and cyanotrihydroborate, $\left[\mathrm{BH}_{3} \mathrm{CN}\right]^{-}$, complexes have been reported, most of the cyanotrihydroborate anion bonds to the metal through a nitrogen atom and, except for five compounds [2a-c] the methyltrihydroborate complexes involve actinide and lanthanide metals. The chemical properties of these organotrihydroborate complexes are not well studied.

In our recent study, we found that the $\mathrm{Zr}-\mathrm{H}-\mathrm{B}$ bond of the methyltrihydroborate disubstituted complex $\mathrm{Cp}_{2} \mathrm{Zr}\left\{(\mu-\mathrm{H})_{2} \mathrm{BHCH}_{3}\right\}_{2}[2 \mathrm{a}]$ is significantly weaker than that of the tetrahydroborate complex $\mathrm{Cp}_{2} \mathrm{Zr}\{(\mu-$ $\left.\mathrm{H})_{2} \mathrm{BH}_{2}\right\}_{2}$ [6] or the organodihydroborate complex $\mathrm{Cp}_{2} \mathrm{Zr}\left\{(\mu-\mathrm{H})_{2} \mathrm{BC}_{5} \mathrm{H}_{10}\right\}_{2}$ [7]. While complex $\mathrm{Cp}_{2} \mathrm{Zr}-$ $\left\{(\mu-\mathrm{H})_{2} \mathrm{BC}_{5} \mathrm{H}_{10}\right\}_{2}$ is stable under vacuum at room temperature and complex $\mathrm{Cp}_{2} \mathrm{Zr}\left\{(\mu-\mathrm{H})_{2} \mathrm{BH}_{2}\right\}_{2}$ can be sublimed under reduced pressure at $120{ }^{\circ} \mathrm{C}$, complex 
$\mathrm{Cp}_{2} \mathrm{Zr}\left\{(\mu-\mathrm{H})_{2} \mathrm{BHCH}_{3}\right\}_{2}$ decomposes to $\mathrm{Cp}_{2} \mathrm{ZrH}\{(\mu-$ $\left.\mathrm{H})_{2} \mathrm{BHCH}_{3}\right\}$ and $\left(\mathrm{CH}_{3} \mathrm{BH}_{2}\right)_{2}$ under vacuum at room temperature [2a]. This weak $\mathrm{Zr}-\mathrm{H}-\mathrm{B}$ bond is unexpected and we proposed that this weak $\mathrm{Zr}-\mathrm{H}-\mathrm{B}$ interaction is caused by the electron releasing property of the methyl group on the boron atom. This effect causes the accumulation of the excess electron density on the central zirconium atom and destabilizes the $\mathrm{Zr}-\mathrm{H}-\mathrm{B}$ interaction. In the present study we are interested to examine this proposition and have selected phenyltrihydroborate complexes for study. We present the syntheses, structures, and the properties of the phenyltrihydroborate derivatives of the zirconocene and titanocene complexes, and we also report the reaction of $\mathrm{Cp}_{2} \mathrm{ZrCl}\left\{(\mu-\mathrm{H})_{2} \mathrm{BHPh}\right\}$ with the Lewis acid, $\mathrm{B}\left(\mathrm{C}_{6} \mathrm{~F}_{5}\right)_{3}$, in non-coordinating and coordinating solvent.

\section{Results and discussion}

2.1. Formation and properties of $\mathrm{Cp}_{2} \mathrm{ZrCl}\left\{(\mu-\mathrm{H})_{2} \mathrm{BHPh}\right\}$ (1), $\mathrm{C} p_{2} \mathrm{Zr}\left\{(\mu-\mathrm{H})_{2} \mathrm{BHPh}_{2} \cdot\left(1 / 2\right.\right.$ toluene) (2), $\mathrm{Cp}_{2} \mathrm{ZrH}$ $\left\{(\mu-H)_{2} B H P h\right\}(3), C p_{2} \mathrm{ZrCl}\left\{(\mu-H)_{2} B\left(C_{6} F_{5}\right)_{2}\right\}$ (4), $\left[\mathrm{Cp}_{2} \mathrm{ZrCl}\left(\mathrm{OEt}_{2}\right)\right]\left[\mathrm{HB}\left(\mathrm{C}_{6} \mathrm{~F}_{5}\right)_{3}\right](5)$, and $\mathrm{Cp}_{2} \mathrm{Ti}\{(\mu-$ $\left.\mathrm{H})_{2} \mathrm{BHPh}\right\}$ (6)

The phenyltrihydroborate compounds $\mathrm{Cp}_{2} \mathrm{ZrCl}\{(\mu$ $\left.\mathrm{H})_{2} \mathrm{BHPh}\right\}, \mathbf{1}$, and $\mathrm{Cp}_{2} \mathrm{Zr}\left\{(\mu-\mathrm{H})_{2} \mathrm{BHPh}\right\}_{2} \cdot(1 / 2$ toluene $)$, 2, were prepared from the reactions of $\mathrm{Cp}_{2} \mathrm{ZrCl}_{2}$ with one and two moles of $\mathrm{LiBH}_{3} \mathrm{Ph}$, as shown in Eqs. (1) and (2). Compound $\mathbf{2}$ was crystallized from toluene solution and contained one-half solvent molecule.
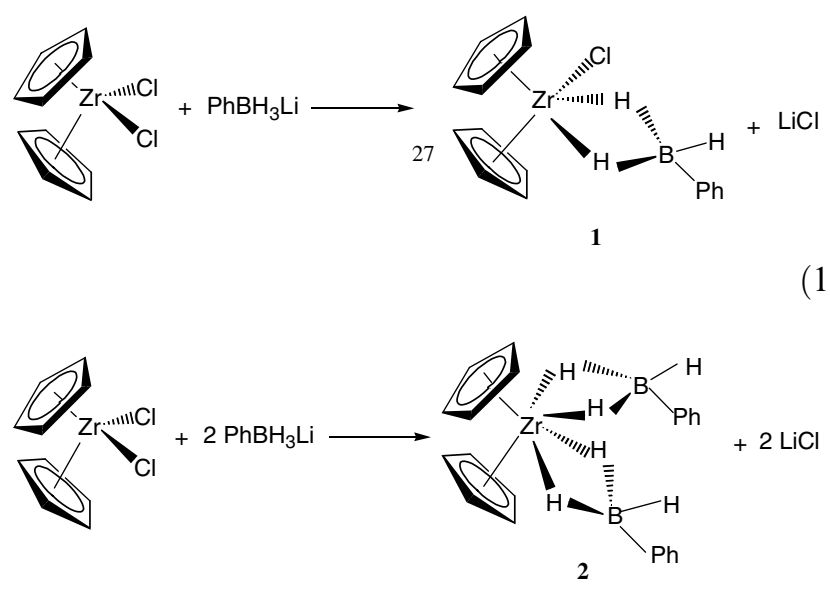

Previously we reported the preparation of the zirconium hydride compound $\mathrm{Cp}_{2} \mathrm{ZrH}\left\{(\mu-\mathrm{H})_{2} \mathrm{BHCH}_{3}\right\}$ through the decomposition of the methyltrihydroborate disubstituted compound $\mathrm{Cp}_{2} \mathrm{Zr}\left\{(\mu-\mathrm{H})_{2} \mathrm{BHCH}_{3}\right\}_{2}$ under reduced pressure at room temperature [2a] (Eq. (3)). An attempt to prepare the zirconium hydride compound $\mathrm{Cp}_{2} \mathrm{ZrH}\left\{(\mu-\mathrm{H})_{2} \mathrm{BHPh}\right\}, \mathbf{3}$, using the same method failed.

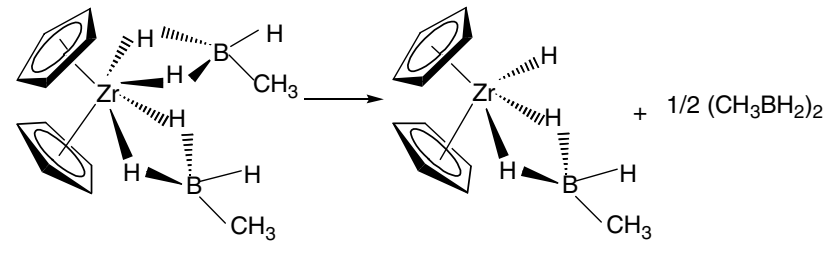

Compound 2 was subjected to sublimation under reduced pressure; however, compound $\mathbf{3}$ did not form, even when the temperature was raised to $100{ }^{\circ} \mathrm{C}$ for $4 \mathrm{~h}$. After heating, most of the crystals turned light pink and the metal luster disappeared. However, the NMR spectra indicated that the compound $\mathrm{Cp}_{2} \mathrm{Zr}\{(\mu-$ $\left.\mathrm{H})_{2} \mathrm{BHPh}\right\}_{2}$ was still intact, and only the absence of the toluene signals was observed. These NMR spectra suggest that the $\mathrm{Zr}-\mathrm{H}-\mathrm{B}$ bond strength of compound $\mathbf{2}$ is comparable to that of the tetrahydroborate complex, $\mathrm{Cp}_{2} \mathrm{Zr}\left\{(\mu-\mathrm{H})_{2} \mathrm{BH}_{2}\right\}_{2}$ [6], which is stable above $100{ }^{\circ} \mathrm{C}$ under reduced pressure. From a steric point of view, the phenyl group on the boron atom has a larger steric requirement than that of the methyl group on compound $\mathrm{Cp}_{2} \mathrm{Zr}\left\{(\mu-\mathrm{H})_{2} \mathrm{BHCH}_{3}\right\}_{2}$, and this factor might destabilize compound $\mathbf{2}$, however, this result was not observed [8]. On the other hand, the inductive effect of the substituent on the boron atom may play a key role for its stability. Formally, the zirconium is associated with 20 valence electrons in compound $\mathbf{2}$, the same as the methyltrihydroborate disubstituted compound $\mathrm{Cp}_{2} \mathrm{Zr}\left\{(\mu-\mathrm{H})_{2} \mathrm{BHCH}_{3}\right\}_{2}$. Unlike the electron donor methyl substituted group on compound $\mathrm{Cp}_{2} \mathrm{Zr}\left\{(\mu-\mathrm{H})_{2} \mathrm{BHCH}_{3}\right\}_{2}$, which directs electron density to the zirconium and weakens the $\mathrm{Zr}-\mathrm{H}-\mathrm{B}$ bond, the electron withdrawing phenyl substituted group on compound 2 relieves the accumulation of excess electron density on the zirconium and stabilizes the $\mathrm{Zr}-\mathrm{H}-\mathrm{B}$ interaction.

Compound 3 can be prepared from the reaction of $\mathrm{Cp}_{2} \mathrm{Zr}\left\{(\mu-\mathrm{H})_{2} \mathrm{BHPh}\right\}_{2}$ with $\mathrm{N}\left(\mathrm{C}_{2} \mathrm{H}_{5}\right)_{3}$ in toluene solution, as shown in Eq. (4).

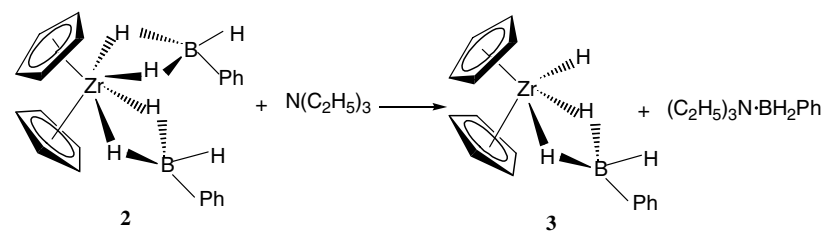

These two products, 3 and $\left(\mathrm{C}_{2} \mathrm{H}_{5}\right)_{3} \mathrm{~N} \cdot \mathrm{BH}_{2} \mathrm{Ph}$, were isolated from repeated crystallizations and manual separations. The second method to prepare compound $\mathbf{3}$ is from the reaction of $\mathrm{Cp}_{2} \mathrm{ZrHCl}$ with $\mathrm{LiBH}_{3} \mathrm{Ph}$ in toluene solution, as shown in Eq. (5). After reacting for one day, only $50 \%$ yield of compound $\mathbf{3}$ was observed from the boron spectra and compound $\mathbf{3}$ did not increase significantly for further reaction. 


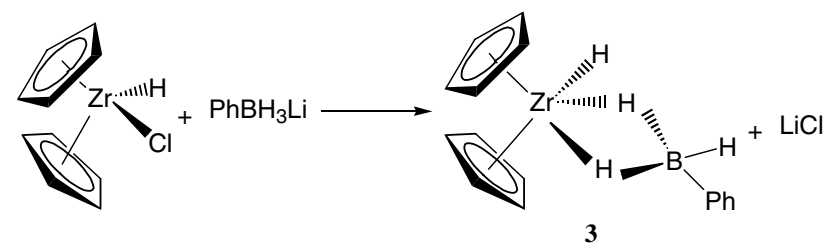

The reaction of 1 with $\mathrm{B}\left(\mathrm{C}_{6} \mathrm{~F}_{5}\right)_{3}$ produces the covalent metathesis product $\mathrm{Cp}_{2} \mathrm{ZrCl}\left\{(\mu-\mathrm{H})_{2} \mathrm{~B}\left(\mathrm{C}_{6} \mathrm{~F}_{5}\right)_{2}\right\}, 4$, in toluene solution, and produces the ionic complex $\left[\mathrm{Cp}_{2} \mathrm{ZrCl}\left(\mathrm{OEt}_{2}\right)\right]\left[\mathrm{HB}\left(\mathrm{C}_{6} \mathrm{~F}_{5}\right)_{3}\right], \quad 5$, in diethyl ether, as shown in Eq. (6).

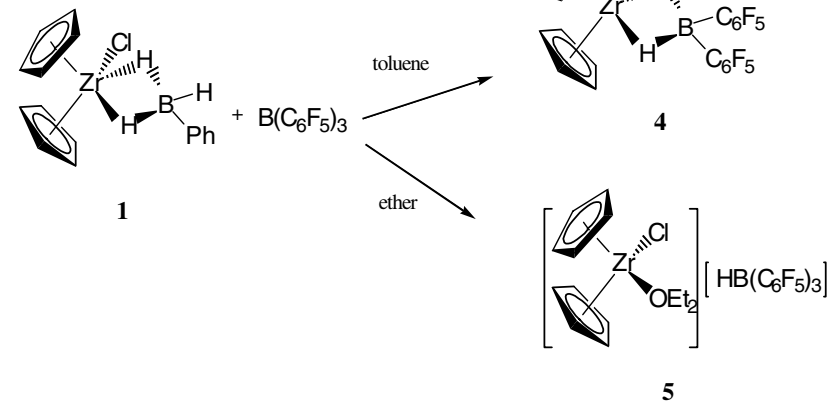

These reactions are not balanced since the by-products could not be identified through an NMR study. We could not prepare pure compound $\mathbf{4}$ on a large scale, since a small amount of by-product could not be removed successfully, however, we isolated a few crystals which were sufficient for the NMR study and the solid state X-ray structure determination. Compound $\mathbf{4}$ has also been prepared from the reaction of $\mathrm{Cp}_{2} \mathrm{ZrHCl}$ with $\mathrm{HB}\left(\mathrm{C}_{6} \mathrm{~F}_{5}\right)_{2}$ in a NMR tube, and identified through a multinuclear NMR spectroscopy [9]. Compound $\mathbf{5}$ is soluble in THF and acetontrile, however, it gradually decomposed in these solvents during the NMR measurements; one of the decomposition products is $\mathrm{Cp}_{2} \mathrm{ZrCl}_{2}$.

The boron chemical shifts of compounds $\mathbf{1}, \mathbf{2}$, and 3 appear as a quartet at $\delta 2.37\left(J_{\mathrm{B}-\mathrm{H}}=76 \mathrm{~Hz}\right),-6.0$ $\left(J_{\mathrm{B}-\mathrm{H}}=70 \mathrm{~Hz}\right)$, and $16.62 \mathrm{ppm}\left(J_{\mathrm{B}-\mathrm{H}}=73 \mathrm{~Hz}\right)$, respectively. The apparent equivalence of bridge and terminal hydrogens of the hydroborate compounds at ambient temperature is well known [1a], which causes the quartet nature of the boron signals. These resonances are downfield with respect to that of lithium phenyltrihydroborate $\left(-26.5 \mathrm{ppm}, J_{\mathrm{B}-\mathrm{H}}=75 \mathrm{~Hz}\right)$. These results are consistent with those obtained from methyltrihydroborate analogs, where the boron chemical shifts of the methyltrihydroborate complexes $\mathrm{Cp}_{2} \mathrm{ZrCl}\left\{(\mu-\mathrm{H})_{2} \mathrm{BHCH}_{3}\right\} \quad$ [2a], $\mathrm{Cp}_{2} \mathrm{Zr}\left\{(\mu-\mathrm{H})_{2} \mathrm{BHCH}_{3}\right\}_{2}$ [2a], and $\mathrm{Cp}_{2} \mathrm{ZrH}\left\{(\mu-\mathrm{H})_{2} \mathrm{BHCH}_{3}\right\}$ [2b] appear at $3.84,-6.82$, and $18.2 \mathrm{ppm}$, respectively. The $\mathrm{B}-\mathrm{H}$ coupling constants of these organotrihydroborate complexes are comparable with that of the free ligands. This behavior is different from that of the tetrahydroborate or cyclic organodihydroborate complexes, which display smaller coupling constants than that of the free ligands $[1 \mathrm{a}, 7,10]$.

In the ${ }^{1} \mathrm{H}$ NMR spectra, the signals of the $\mathrm{BH}_{3}$ hydrogens of complexes $\mathbf{1}, \mathbf{2}$, and $\mathbf{3}$ appeared at 1.00 , 1.39 , and $-0.42 \mathrm{ppm}$, as a broad quartet, respectively. The terminal and bridge hydrogens in these complexes are indistinguishable in the proton spectra [1a]. The chemical shift of the terminal $\mathrm{Zr}-\mathrm{H}$ hydride of compound 3 appears at $4.48 \mathrm{ppm}$, as a broad signal that falls within the range observed for other zirconium hydride complexes [2b, 6b,7,12,13].

The boron signal of compound 4 appears at -10.6 ppm $\left(\mathrm{t}, J_{\mathrm{B}-\mathrm{H}}=67 \mathrm{~Hz}\right)$. This chemical shift and coupling constant are consistent with that of the bis(pentafluorophenyl)borate zirconocene complexes $[9,14]$. The bridge $\mathrm{Zr}-\mathrm{H}-\mathrm{B}$ hydrogens appear at $0.38 \mathrm{ppm}$ as a broad signal.

The NMR data of compound $\mathbf{5}$ was collected in deuteriated THF where the coordinating ether was replaced by the deuteriated THF. The terminal $\mathrm{B}-\mathrm{H}$ hydrogen appeared at $3.80 \mathrm{ppm}$ as a broad quartet. The anionic borate signal appeared at $-25.9 \mathrm{ppm}$ as a doublet $\left(J_{\mathrm{B}-\mathrm{H}}=93 \mathrm{~Hz}\right)$ in the boron spectrum. These chemical shifts and coupling constant are consistent with other ionic complexes with the same anion [15].

The IR spectrum of compound $\mathbf{3}$ displays a broad signal at $1597 \mathrm{~cm}^{-1}$ assigned to the $\mathrm{Zr}-\mathrm{H}$ stretching mode, which agrees with bands observed in the IR spectra of other zirconium hydride complexes $[2 \mathrm{~b}, 6 \mathrm{~b}, 7,12]$.

Compound $\mathrm{Cp}_{2} \mathrm{Ti}\left\{(\mu-\mathrm{H})_{2} \mathrm{BHPh}\right\}$, 6, was prepared from the reaction of $\mathrm{Cp}_{2} \mathrm{TiCl}_{2}$ with two moles of $\mathrm{LiBH}_{3} \mathrm{Ph}$, as shown in Eq. (7).

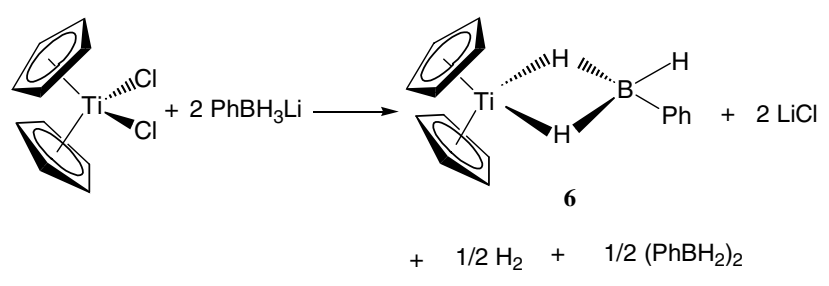

During the reaction, hydrogen gas was evolved and the solution turned purple in color. The titanium was reduced from $\mathrm{Ti}(\mathrm{IV})$ to $\mathrm{Ti}(\mathrm{III})$, producing a 17-electron species. No obvious signal was observed in the \pm 100 ppm range in the boron spectra. In the ${ }^{1} \mathrm{H}$ NMR spectrum, three signals were observed in the range 6.55$7.68 \mathrm{ppm}$. These signals appeared in the range of the aromatic protons and were assigned to the resonances of the phenyl protons, using a proton detected ${ }^{1} \mathrm{H}^{13} \mathrm{C}$ correlation experiment (heteronuclear multiple quantum 
coherence, HMQC). A broad signal that appeared at $7.68 \mathrm{ppm}$ was assigned to the resonance of the $\beta$ proton of the phenyl group, which is five bonds away from the paramagnetic center. This result is consistent with our previous study of the cyclic organohydroborate complexes of titanocene where the proton signals are NMR silent until they are five bonds away from the paramagnetic center [16].

\subsection{Molecular structures}

The molecular structures of $\mathbf{1}, \mathbf{2}, \mathbf{3}, \mathbf{4}, \mathbf{5}$, and $\mathbf{6}$ were determined by single-crystal X-ray diffraction analysis, and they are shown in Figs. 1-6. Crystallographic data and selected bond distances and bond angles are given in Tables 1-4. A complete listing of distances and angles, as well as the atomic coordinates, can be found in the Supporting Information.

The coordination geometry around the zirconium atom in $\mathbf{1}, \mathbf{2}, \mathbf{3}$, and $\mathbf{4}$ is best described as a distorted tetrahedron. At the corners of the tetrahedron are the centers of the two $\mathrm{Cp}$ rings, a boron atom which is connected to the zirconium through two bridge hydrogens, and a $\mathrm{Cl}$ (1 and 4), or a second boron atom (2) which is also connected to the zirconium through two bridge hydrogens, or a hydrogen atom (3). Two independent molecules of $\mathbf{4}$ were found in the unit cell. These two molecules have slightly different bond distances and angles, and only one molecule is shown in Fig. 4.

In compound 2, one-half solvent molecule, toluene, was found in the crystal lattice and one $\mathrm{Cp}$ ring displayed $50 \%$ occupancy. There is a crystallographically imposed mirror plane which passes through the $\mathrm{Zr}$, $C(7), C(15), C(16)$, and $C(19)$, to generate the rest of the molecule. The carbon atoms $\mathrm{C}(15), \mathrm{C}(16)$, and $\mathrm{C}(19)$ are from the solvent, they are not shown in Fig. 2. The four bridge hydrogens are coplanar. The coplanarity of the four bridge hydrogens in $\mathrm{Cp}_{2} \mathrm{Zr}\left\{(\mu-\mathrm{H})_{2} \mathrm{BH}_{2}\right\}_{2}$ has been

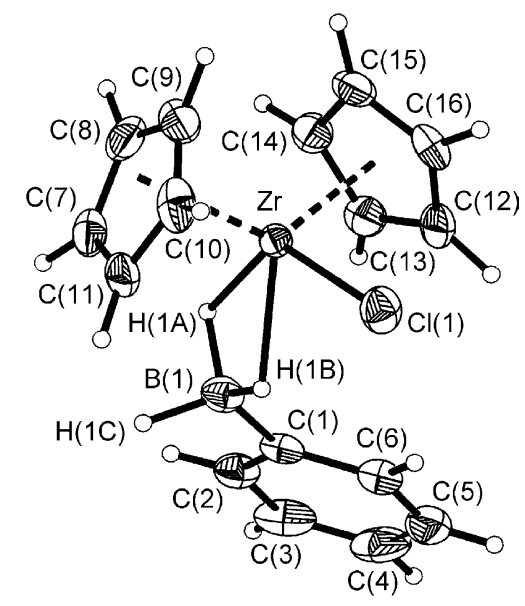

Fig. 1. Molecular structure of $\mathrm{Cp}_{2} \mathrm{ZrCl}\left\{(\mu-\mathrm{H})_{2} \mathrm{BHPh}\right\}$ (1), showing $50 \%$ probability thermal ellipsoids.

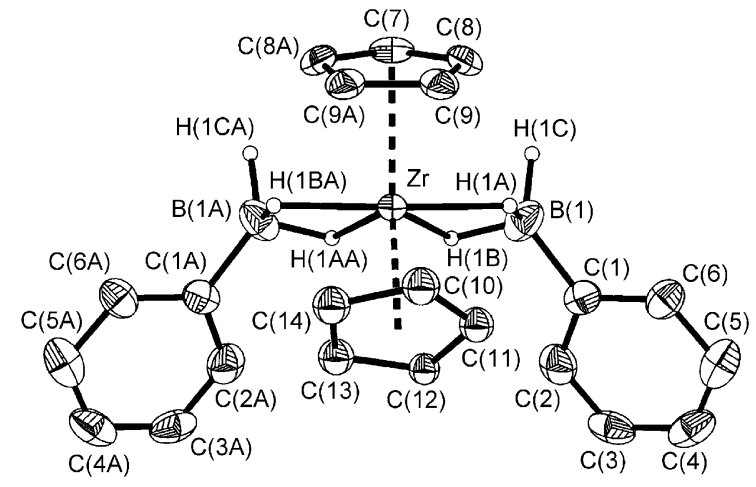

Fig. 2. Molecular structure of $\mathrm{Cp}_{2} \mathrm{Zr}\left\{(\mu-\mathrm{H})_{2} \mathrm{BHPh}\right\}_{2} \cdot(1 / 2$ toluene $)$ (2), showing $50 \%$ probability thermal ellipsoids. Toluene molecule is omitted.

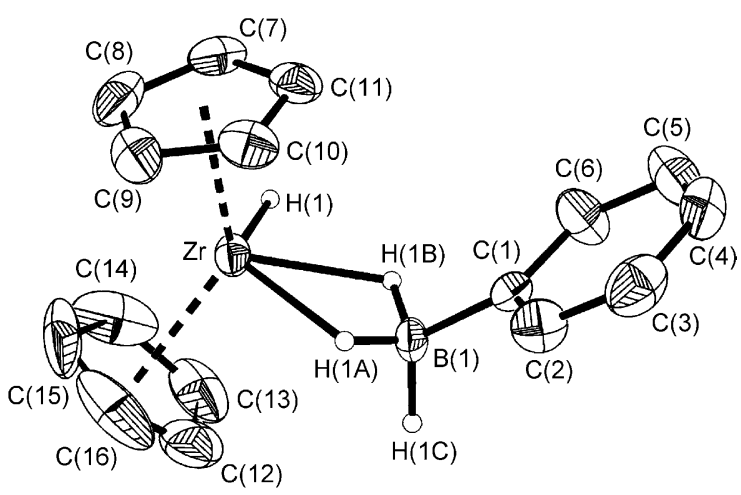

Fig. 3. Molecular structure of $\mathrm{Cp}_{2} \mathrm{ZrH}\left\{(\mu-\mathrm{H})_{2} \mathrm{BHPh}\right\}$ (3), showing $50 \%$ probability thermal ellipsoids.

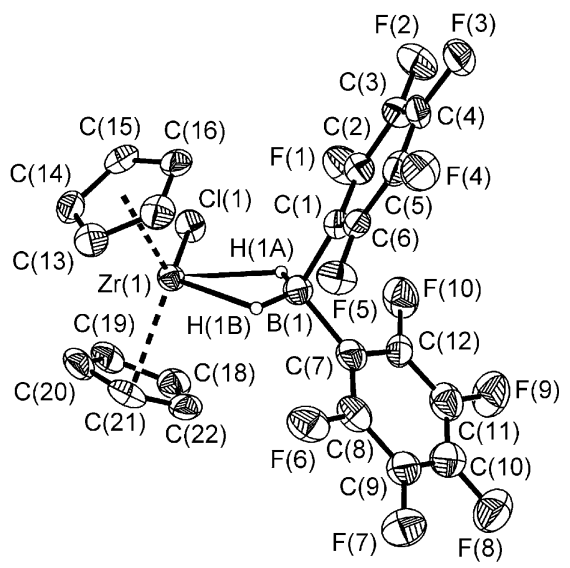

Fig. 4. Molecular structure of $\mathrm{Cp}_{2} \mathrm{ZrCl}\left\{(\mu-\mathrm{H})_{2} \mathrm{~B}\left(\mathrm{C}_{6} \mathrm{~F}_{5}\right)_{2}\right\}$ (4), showing $50 \%$ probability thermal ellipsoids.

suggested by Hoffmann and Lauher through molecular orbital calculations [17]. Although the solid state structure of $\mathrm{Cp}_{2} \mathrm{Zr}\left\{(\mu-\mathrm{H})_{2} \mathrm{BH}_{2}\right\}_{2}$ has been reported, hydrogen atoms around the boron atom were not found due to the low quality of the crystal [18]. Some metallocene hydroborate disubstituted complexes have been reported, which include $\left(\mathrm{C}_{5} \mathrm{H}_{4} \mathrm{Me}\right)_{2} \mathrm{Hf}\left\{(\mu-\mathrm{H})_{2} \mathrm{BH}_{2}\right\}_{2}$ [19], 


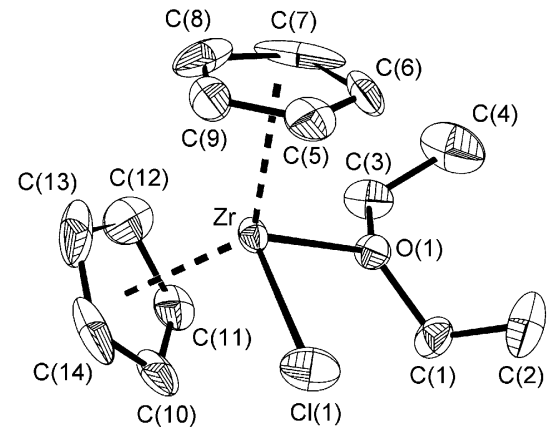

Fig. 5. Molecular structure of the cation $\left[\mathrm{Cp}_{2} \mathrm{ZrCl}\left(\mathrm{OC}_{4} \mathrm{H}_{10}\right)\right]^{+}(\mathbf{5})$, showing $30 \%$ probability thermal ellipsoids.

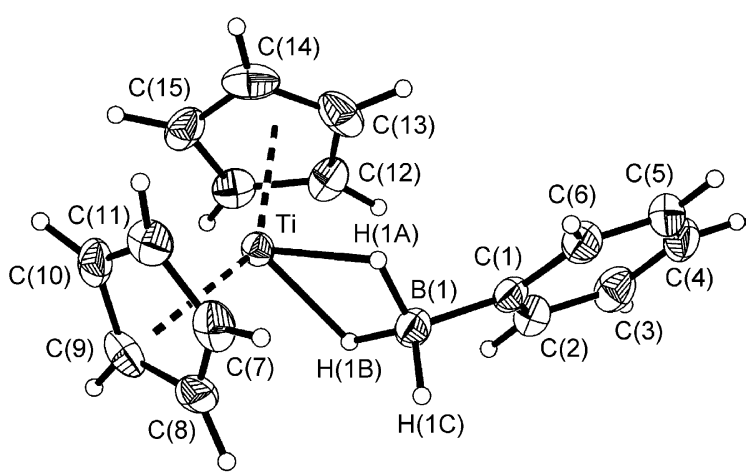

Fig. 6. Molecular structure of $\mathrm{Cp}_{2} \operatorname{Ti}\left\{(\mu-\mathrm{H})_{2} \mathrm{BHPh}\right\}$ (6), showing $50 \%$ probability thermal ellipsoids.

$\mathrm{Cp}_{2} \mathrm{Zr}\left\{(\mu-\mathrm{H})_{2} \mathrm{BC}_{5} \mathrm{H}_{10}\right\}_{2} \quad$ [7], $\quad \mathrm{Cp}_{2} \mathrm{Zr}\left\{(\mu-\mathrm{H})_{2} \mathrm{BHCH}_{3}\right\}_{2}$ [2a], and $\mathrm{Cp}_{2} \mathrm{Zr}\left\{(\mu-\mathrm{H})_{2} \mathrm{~B}\left(\mathrm{C}_{6} \mathrm{H}_{5}\right)_{2}\right\}_{2}$ [9], the bridge hydrogen atoms in these compounds are not coplanar. In compound 2, the zirconium atom is $0.1831 \AA$ above, and each boron atom is $0.1719 \AA$ below the plane defined by the four bridge hydrogens. The $\mathrm{B}-\mathrm{Zr}-\mathrm{B}$ angle of 2 is $107.9(3)^{\circ}$ which is larger than that in compounds $\mathrm{Cp}_{2} \mathrm{Zr}\left\{(\mu-\mathrm{H})_{2} \mathrm{BH}_{2}\right\}_{2} \quad\left(103.3(7)^{\circ}\right) \quad[18], \quad \mathrm{Cp}_{2} \mathrm{Zr}\{(\mu-$ $\left.\mathrm{H})_{2} \mathrm{BC}_{5} \mathrm{H}_{10}\right\}_{2}\left(89.3^{\circ}\right)$ [7] and $\mathrm{Cp}_{2} \mathrm{Zr}\left\{(\mu-\mathrm{H})_{2} \mathrm{BHCH}_{3}\right\}_{2}$ $\left(99.7(3)^{\circ}\right)[2 \mathrm{a}, 20]$.

The $\mathrm{Zr}-\mathrm{B}$ distances are 2.592(4) in 1, 2.628(6) in $\mathbf{2}$, and 2.538(11) $\AA$ in 3. These distances reflect the steric bulk of the fourth ligand which is $\mathrm{Cl}(\mathbf{1}), \mathrm{BH}_{3} \mathrm{Ph}$ (2), and $\mathrm{H}(3)$, respectively. However, an interesting result is observed when these distances are compared with those in the methyltrihydroborate analogs: $\mathrm{Cp}_{2} \mathrm{ZrCl}-$ $\left\{(\mu-\mathrm{H})_{2} \mathrm{BHCH}_{3}\right\} \quad(2.578(6) \quad \AA) \quad[2 \mathrm{a}], \quad \mathrm{Cp}_{2} \mathrm{Zr}\{(\mu-$ $\left.\mathrm{H})_{2} \mathrm{BHCH}_{3}\right\}_{2} \quad(2.599(8)$ and 2.612(9) $\AA$ ) [2a], and $\mathrm{Cp}_{2} \mathrm{ZrH}\left\{(\mu-\mathrm{H})_{2} \mathrm{BHCH}_{3}\right\} \quad(2.558(4) \AA)[2 \mathrm{~b}]$. Although the phenyl substituted compounds $\mathbf{1}$ and $\mathbf{2}$ have longer $\mathrm{Zr}-\mathrm{B}$ distances compared with the methyltrihydroborate analogs, compound $\mathbf{3}$ has a shorter $\mathrm{Zr}-\mathrm{B}$ distance than that in compound $\mathrm{Cp}_{2} \mathrm{ZrH}\left\{(\mu-\mathrm{H})_{2} \mathrm{BHCH}_{3}\right\}$. Obviously, the steric bulk of the phenyl substituted group alone does not account for the discrepancy in these distances. Compared with other ligands, the hydride ligand is relatively small and the steric effect is minimal. This may suggest the electronic effect dominates the metalligand interaction. Support for this argument is given by the two cyclic organodihydroborate compounds, $\mathrm{Cp}_{2} \mathrm{ZrH}\left\{(\mu-\mathrm{H})_{2} \mathrm{BC}_{5} \mathrm{H}_{10}\right\}$ (2.587(7) $\AA$ ) [7] and $\mathrm{Cp}_{2} \mathrm{ZrH}-$ $\left\{(\mu-\mathrm{H})_{2} \mathrm{BC}_{4} \mathrm{H}_{8}\right\}(2.548(4) \AA)$ [12], both have an electron releasing alkyl group, which have $\mathrm{Zr}-\mathrm{B}$ distances comparable to that in $\mathrm{Cp}_{2} \mathrm{ZrH}\left\{(\mu-\mathrm{H})_{2} \mathrm{BHCH}_{3}\right\}$, but are longer than that observed in the electron withdrawing substituted compound 3 .

The $\mathrm{Zr}-\mathrm{B}$ distance is $2.604(8) \AA$ in 4 . It is slightly longer than that in $\mathbf{1}$, however, it is significantly shorter than the $\mathrm{Zr}-\mathrm{B}$ distances found in the bulky bis(pentafluorophenyl)borate compound $\mathrm{Cp}_{2} \mathrm{Zr}\left\{(\mu-\mathrm{H})_{2} \mathrm{~B}\right.$ $\left.\left(\mathrm{C}_{6} \mathrm{~F}_{5}\right)_{2}\right\}_{2}(2.696(10)$ and 2.679(10) $\AA$ ), due to the steric reason [14].

The bridge $\mathrm{Zr}-\mathrm{H}_{\mathrm{b}}$ and bridge $\mathrm{B}-\mathrm{H}_{\mathrm{b}}$ distances of compounds 1-4 are listed in Table 3. Comparing with the bridge $\mathrm{Zr}-\mathrm{H}$ distances (1.96(5)-2.17(9) $\AA$ ) and the bridge B-H distances (1.10(9)-1.32(5) $\AA$ ) of the zirconocene hydroborate complexes [2a, 7,9,12,21], compound 3 has a shorter bridge B-H distance and compound 4 has a longer $\mathrm{Zr}-\mathrm{H}$ distance. These may account for the short $\mathrm{Zr}-\mathrm{B}$ distance in $\mathbf{3}$ and long $\mathrm{Zr}-\mathrm{B}$ distance in $\mathbf{4}$.

The terminal $\mathrm{B}-\mathrm{H}_{\mathrm{t}}$ bond distances of $\mathbf{1}(1.22(5) \AA), 2$ (1.21(6) $\AA$ ), and 3 (1.14(6) $\AA$ ) are comparable with one of the bridge $\mathrm{B}-\mathrm{H}$ bond distances and are longer than the other one found in each compound. These results are different compared with those were observed in the tetrahydroborate complexes where the bridge $\mathrm{B}-\mathrm{H}$ bond distances are $0.06-0.10 \AA$ longer than the terminal B-H bond distances [1a,21].

The $\mathrm{Zr}-\mathrm{Cl}$ distance is 2.4844(13) $\AA$ in 1 and 2.460(2) $\AA$ in 4. It is comparable to the $\mathrm{Zr}-\mathrm{Cl}$ distances observed in other hydroborate complexes [2a,10,22].

The terminal $\mathrm{Zr}-\mathrm{H}$ distance in 3 is $1.70(7) \AA$. This distance is significantly shorter than that in $\left(\eta^{5}\right.$ $\left.\mathrm{C}_{5} \mathrm{Me}_{5}\right) \mathrm{ZrH}\left(\eta-\mathrm{C}_{8} \mathrm{H}_{8}\right) \quad(1.81 \quad \AA) \quad[23], \quad \mathrm{Cp}_{2} \mathrm{ZrH}\{(\mu-$ $\left.\mathrm{H})_{2} \mathrm{BC}_{5} \mathrm{H}_{10}\right\}$ (1.786(4) $\AA$ ) [7], $\mathrm{Cp}_{2} \mathrm{ZrH}\left\{(\mu-\mathrm{H})_{2} \mathrm{BHCH}_{3}\right\}$ $(1.78(2) \quad \AA) \quad[2 \mathrm{~b}]$, and $\left\{\mathrm{ZrH}(\mu-\mathrm{H})\left(\eta-\mathrm{C}_{5} \mathrm{H}_{4} \mathrm{Me}\right)_{2}\right\}_{2}$ (1.78(2) $\AA$ ) [24], but is comparable to those distances observed in $\mathrm{Cp}_{2} \mathrm{ZrH}\left\{(\mu-\mathrm{H})_{2} \mathrm{BC}_{4} \mathrm{H}_{8}\right\}$ (1.68(5) $\AA$ ) [12] and $\left(\eta^{5}-\mathrm{C}_{8} \mathrm{H}_{11}\right) \mathrm{ZrH}(\mathrm{dmpe})(1.67 \AA)$ [25].

The coordination geometry around the zirconium atom in $\mathbf{5}$ is best described as a distorted tetrahedron, where the centers of the two $\mathrm{Cp}$ rings, a chlorine atom, and an oxygen atom occupy the corners of the tetrahedron. The $\mathrm{Zr}-\mathrm{Cl}$ distance is $2.4148(17) \AA$ and the $\mathrm{Zr}-\mathrm{O}$ distance is 2.211(3) $\AA$. The $\mathrm{Zr}-\mathrm{Cl}$ distance is slightly shorter than that in compounds $\mathbf{1}, \mathbf{4}$, and other organohydroborate compound [2a,10,22]. The $\mathrm{Zr}-\mathrm{O}$ distance was consistent with that observed in $\left[\mathrm{Cp}_{2} \mathrm{Zr}\left(\mathrm{OEt}_{2}\right)\right.$ $(\mathrm{OEt})]\left[\mathrm{HB}\left(\mathrm{C}_{6} \mathrm{~F}_{5}\right)\right](2.209(8) \AA)$ [15] and is slightly longer than the sum of the covalent radii, $2.16 \AA$ [26]. These bond distances suggest a weak interaction between the zirconium atom and the ether molecule, which has been 
Table 1

Crystallographic data for $\mathrm{Cp}_{2} \mathrm{ZrCl}\left\{(\mu-\mathrm{H})_{2} \mathrm{BHPh}\right\}(\mathbf{1}), \mathrm{Cp}_{2} \mathrm{Zr}\left\{(\mu-\mathrm{H})_{2} \mathrm{BHPh}\right\}_{2} \cdot(1 / 2$ toluene $)(\mathbf{2})$, and $\mathrm{Cp}{ }_{2} \mathrm{ZrH}\left\{(\mu-\mathrm{H})_{2} \mathrm{BHPh}\right\}(\mathbf{3})$

\begin{tabular}{|c|c|c|c|}
\hline Empirical formula & $\mathrm{C}_{16} \mathrm{H}_{18} \mathrm{BClZr}$ & $\mathrm{C}_{25.5} \mathrm{H}_{30} \mathrm{~B}_{2} \mathrm{Zr}$ & $\mathrm{C}_{16} \mathrm{H}_{19} \mathrm{BZr}$ \\
\hline$F_{\mathrm{w}}$ & 347.78 & 449.33 & 313.34 \\
\hline$T(\mathrm{~K})$ & $150(1)$ & $150(1)$ & $150(1)$ \\
\hline Cryst system & Monoclinic & Tetragonal & Monoclinic \\
\hline Space group & $C c$ & $P \overline{4} 2_{1} m$ & $P n$ \\
\hline$a(\AA)$ & $17.5766(3)$ & $16.9483(2)$ & $6.1535(1)$ \\
\hline$b(\AA)$ & $8.8102(2)$ & $16.9483(2)$ & $8.2688(2)$ \\
\hline$c(\AA)$ & $11.0359(2)$ & $7.9935(1)$ & $14.5763(3)$ \\
\hline \multicolumn{4}{|l|}{$\alpha\left(^{\circ}\right)$} \\
\hline$\beta\left(^{\circ}\right)$ & $114.0895(9)$ & & $99.9431(13)$ \\
\hline \multicolumn{4}{|l|}{$\gamma\left({ }^{\circ}\right)$} \\
\hline$V\left(\AA^{3}\right)$ & $1560.11(5)$ & $2296.09(5)$ & $730.53(3)$ \\
\hline$Z$ & 4 & 4 & 2 \\
\hline$\rho_{\text {calc. }}\left(\mathrm{g} / \mathrm{cm}^{3}\right)$ & 1.481 & 1.300 & 1.424 \\
\hline Cryst size $\left(\mathrm{mm}^{3}\right)$ & $0.40 \times 0.32 \times 0.25$ & $0.25 \times 0.25 \times 0.23$ & $0.30 \times 0.20 \times 0.16$ \\
\hline Radiation $(\lambda, \AA)$ & Mo K $\alpha(0.71073)$ & Mo $\mathrm{K} \alpha(0.71073)$ & Mo $\mathrm{K} \alpha(0.71073)$ \\
\hline $2 \theta$ Limits $\left(^{\circ}\right)$ & $2.54-27.49$ & $1.70-27.50$ & $2.46-27.50$ \\
\hline \multirow[t]{3}{*}{ Index ranges } & $-22 \leqslant h \leqslant 22$ & $-22 \leqslant h \leqslant 21$ & $-7 \leqslant h \leqslant 7$ \\
\hline & $-10 \leqslant k \leqslant 11$ & $-22 \leqslant k \leqslant 22$ & $-10 \leqslant k \leqslant 10$ \\
\hline & $-14 \leqslant l \leqslant 14$ & $-10 \leqslant l \leqslant 10$ & $-18 \leqslant l \leqslant 17$ \\
\hline Reflns collected & 9597 & 16177 & 9723 \\
\hline Unique reflns & 3331 & 2759 & 3112 \\
\hline Unique reflns $[I>2.0 \sigma(I)]$ & 704 & 932 & 320 \\
\hline Completeness to $\theta(\%)$ & 99.8 & 100.0 & 99.9 \\
\hline$\mu\left(\mathrm{mm}^{-1}\right)$ & 0.859 & 0.487 & 0.732 \\
\hline $\mathrm{Max} / \min \operatorname{transm}$ & $0.843,0.738$ & $0.888,0.821$ & $0.881,0.799$ \\
\hline Data/restraints/parameters & $3331 / 2 / 185$ & $2759 / 0 / 136$ & $3112 / 2 / 177$ \\
\hline$R_{1}^{\mathrm{a}}[I>2.0 \sigma(I)]$ & 0.0329 & 0.0462 & 0.0387 \\
\hline$w R_{2}{ }^{\mathrm{b}}$ (all data) & 0.0919 & 0.1153 & 0.1003 \\
\hline$R_{\text {int }}$ & 0.0446 & 0.0731 & 0.0460 \\
\hline GOF on $F^{2}$ & 1.192 & 1.118 & 1.145 \\
\hline
\end{tabular}

${ }^{\mathrm{a}} R_{1}=\sum\left\|F_{\mathrm{o}}\right\|-\left|F_{\mathrm{c}}\left\|/ \sum\right\| F_{\mathrm{o}}\right|$.

${ }^{\mathrm{b}}{ } w R_{2}=\left\{\sum w\left(F_{\mathrm{o}}^{2}-F_{\mathrm{c}}^{2}\right)^{2} / \sum w\left(F_{\mathrm{o}}^{2}\right)^{2}\right\}^{1 / 2}$.

confirmed through a NMR study where the coordinated ether molecule was replaced by the THF molecule.

The coordination geometry of the titanium atom in compound $\mathbf{6}$ is best described as a trigonal. The centers of the two $\mathrm{Cp}$ rings and the boron atom which is connected to the titanium atom through two bridge hydrogens define the trigonal coordination geometry of the metal center. The bond distances of $\mathrm{Ti}-\mathrm{B}$, bridge $\mathrm{Ti}-$ $\mathrm{H}_{\mathrm{b}}$, and bridge $\mathrm{B}-\mathrm{H}_{\mathrm{b}}$ are all consistent with those in other titanocene organohydroborate complexes $[2 \mathrm{a}, 15,16,27]$. The terminal $\mathrm{B}-\mathrm{H}$ distance of 1.14(2) $\AA$ is shorter than the bridge $\mathrm{B}-\mathrm{H}$ distances.

\section{Experimental}

\subsection{General procedures}

All manipulations were carried out using a standard high vacuum line or in a drybox under an atmosphere of nitrogen. Diethyl ether and toluene were dried over $\mathrm{Na}$ /benzophenone and were freshly distilled prior to use. $\mathrm{Cp}_{2} \mathrm{ZrCl}_{2}, \mathrm{Cp}_{2} \mathrm{TiCl}_{2}$, and $\mathrm{LiAlH}_{4}$ were purchased from Aldrich and used as received. $\mathrm{PhB}(\mathrm{OH})_{2}$ and
$\mathrm{B}\left(\mathrm{C}_{6} \mathrm{~F}_{5}\right)_{3}$ were purchased from Strem and used as received. $\mathrm{LiBH}_{3} \mathrm{Ph}$ was prepared according to the literature method [11a]. Elemental analyses were recorded on a Hitachi $270-30$ spectrometer. ${ }^{1} \mathrm{H}$ NMR spectra $(\delta$ (TMS) $0.00 \mathrm{ppm}$ ) were recorded on a Varian Mercury 200 spectrometer operating at $199.975 \mathrm{MHz}$ or recorded on a Varian Unity Inova 600 spectrometer operating at $599.948 \mathrm{MHz} .{ }^{11} \mathrm{~B}$ spectra (externally referenced to $\left.\mathrm{BF}_{3} \cdot \mathrm{OEt}_{2}(\delta 0.00 \mathrm{ppm})\right)$ were recorded on a Varian Unity Inova 600 operating at $192.481 \mathrm{MHz}$. Infrared spectra were recorded on a Jasco FT/IR-460 Plus spectrometer with $2 \mathrm{~cm}^{-1}$ resolution.

\subsection{X-ray crystal structure determination}

Suitable single crystals of $\mathbf{1}, \mathbf{2}, \mathbf{3}, \mathbf{4}, \mathbf{5}$, and $\mathbf{6}$ were mounted and sealed inside glass capillaries under nitrogen. Crystallographic data collections were carried out on a Nonius KappaCCD diffractometer equipped with graphite-monochromated Mo $\mathrm{K} \alpha$ radiation $(\lambda=$ $0.71073 \AA$ ) at $150(1) \mathrm{K}$. Cell parameters were retrieved and refined using DENZO-SMN [28] software on all reflections. Data reduction was performed with the DENZO-SMN [28] software. An empirical absorption was based on the symmetry-equivalent reflections and 
Table 2

Crystallographic data for $\mathrm{Cp}_{2} \mathrm{ZrCl}\left\{(\mu-\mathrm{H})_{2} \mathrm{~B}\left(\mathrm{C}_{6} \mathrm{~F}_{5}\right)_{2}\right\}$ (4), $\left[\mathrm{Cp}_{2} \mathrm{ZrCl}\left(\mathrm{OC}_{4} \mathrm{H}_{10}\right)\right]\left[\mathrm{HB}\left(\mathrm{C}_{6} \mathrm{~F}_{5}\right)\right](\mathbf{5})$, and $\mathrm{Cp}_{2} \mathrm{Ti}\left\{(\mu-\mathrm{H})_{2} \mathrm{BHPh}\right\}(\mathbf{6})$

\begin{tabular}{|c|c|c|c|}
\hline Empirical formula & $\mathrm{C}_{22} \mathrm{H}_{12} \mathrm{~B}_{2} \mathrm{ClF}_{10} \mathrm{Zr}$ & $\mathrm{C}_{32} \mathrm{H}_{21} \mathrm{BClF}_{15} \mathrm{OZr}$ & $\mathrm{C}_{16} \mathrm{H}_{18} \mathrm{BTi}$ \\
\hline$F_{\mathrm{w}}$ & 603.8 & 843.97 & 269.01 \\
\hline$T(\mathrm{~K})$ & $150(1)$ & $150(1)$ & $150(1)$ \\
\hline Crystal system & Triclinic & Monoclinic & Orthorhombic \\
\hline Space group & $P \overline{1}$ & $P 2_{1} / n$ & $P b c a$ \\
\hline$a(\AA)$ & $7.3519(1)$ & $12.5124(6)$ & $11.47130(10)$ \\
\hline$b(\AA)$ & $16.2967(3)$ & $20.5626(10)$ & $14.3734(2)$ \\
\hline$c(\AA)$ & $18.1612(3)$ & $12.9849(6)$ & $16.7301(2)$ \\
\hline$\alpha\left({ }^{\circ}\right)$ & $89.9137(7)$ & & \\
\hline$\beta\left(\left(^{\circ}\right)\right.$ & $89.1789(7)$ & $106.118(1)$ & \\
\hline$\gamma\left({ }^{\circ}\right)$ & $83.7631(6)$ & & \\
\hline$V\left(\AA^{3}\right)$ & $2162.82(6)$ & $3209.5(3)$ & $2758.49(6)$ \\
\hline$Z$ & 4 & 4 & 8 \\
\hline$\rho_{\text {calc. }}\left(\mathrm{g} / \mathrm{cm}^{3}\right)$ & 1.854 & 1.747 & 1.296 \\
\hline Cryst size $\left(\mathrm{mm}^{3}\right)$ & $0.25 \times 0.25 \times 0.10$ & $0.23 \times 0.20 \times 0.15$ & $0.25 \times 0.20 \times 0.10$ \\
\hline Radiation $(\lambda, \AA ̊)$ & Mo K $\alpha(0.71073)$ & Mo K $\alpha(0.71073)$ & Mo $\mathrm{K} \alpha(0.71073)$ \\
\hline $2 \theta$ Limits $\left({ }^{\circ}\right)$ & $1.12-27.50$ & $1.91-27.50$ & $2.43-27.50$ \\
\hline \multirow[t]{3}{*}{ Index ranges } & $-9 \leqslant h \leqslant 9$ & $-15 \leqslant h \leqslant 16$ & $-14 \leqslant h \leqslant 14$ \\
\hline & $-21 \leqslant k \leqslant 21$ & $-26 \leqslant k \leqslant 26$ & $-18 \leqslant k \leqslant 18$ \\
\hline & $-23 \leqslant l \leqslant 23$ & $-16 \leqslant l \leqslant 15$ & $-21 \leqslant l \leqslant 21$ \\
\hline Reflns collected & 29319 & 29319 & 20458 \\
\hline Uique reflns & 9824 & 7372 & 3166 \\
\hline Uique reflns $[I>2.0 \sigma(I)]$ & 1184 & 1672 & 1128 \\
\hline Cmpleteness to $\theta(\%)$ & 98.6 & 99.9 & 99.9 \\
\hline$\mu\left(\mathrm{mm}^{-1}\right)$ & 0.727 & 0.541 & 0.598 \\
\hline Max/min transm & $0.943,0.821$ & $0.9233,0.8857$ & $0.945,0.859$ \\
\hline Data/restraints/parameters & $9824 / 1 / 648$ & $7372 / 0 / 464$ & $3166 / 0 / 176$ \\
\hline$R_{1}^{\mathrm{a}}[I>2.0 \sigma(I)]$ & 0.0785 & 0.0707 & 0.0364 \\
\hline$w R_{2}^{\mathrm{b}}$ (all data) & 0.2344 & 0.1787 & 0.0985 \\
\hline$R_{\text {int }}$ & 0.0655 & 0.0525 & 0.0507 \\
\hline GOF on $F^{2}$ & 1.098 & 1.062 & 1.051 \\
\hline
\end{tabular}

${ }^{\mathrm{a}} R_{1}=\sum\left\|F_{\mathrm{o}}\right\|-\left|F_{\mathrm{c}}\left\|/ \sum\right\| F_{\mathrm{o}}\right|$.

${ }^{\mathrm{b}} w R_{2}=\left\{\sum w\left(F_{\mathrm{o}}^{2}-F_{\mathrm{c}}^{2}\right)^{2} / \sum w\left(F_{\mathrm{o}}^{2}\right)^{2}\right\}^{1 / 2}$.

Table 3

Selected bond distances $(\AA)$ and bond angles $\left(^{\circ}\right)$ for $\mathrm{Cp}_{2} \mathrm{ZrCl}\left\{(\mu-\mathrm{H})_{2} \mathrm{BHPh}\right\}(\mathbf{1}), \mathrm{Cp}_{2} \mathrm{Zr}\left\{(\mu-\mathrm{H})_{2} \mathrm{BHPh}\right\}_{2} \cdot(1 / 2$ toluene $)(\mathbf{2}), \mathrm{Cp} \mathrm{p}_{2} \mathrm{ZrH}\left\{(\mu-\mathrm{H})_{2} \mathrm{BHPh}\right\}(\mathbf{3})$, $\mathrm{Cp}_{2} \mathrm{ZrCl}\left\{(\mu-\mathrm{H})_{2} \mathrm{~B}\left(\mathrm{C}_{6} \mathrm{~F}_{5}\right)_{2}\right\}$ (4), and $\mathrm{Cp}_{2} \mathrm{Ti}\left\{(\mu-\mathrm{H})_{2} \mathrm{BHPh}\right\}$ (6)

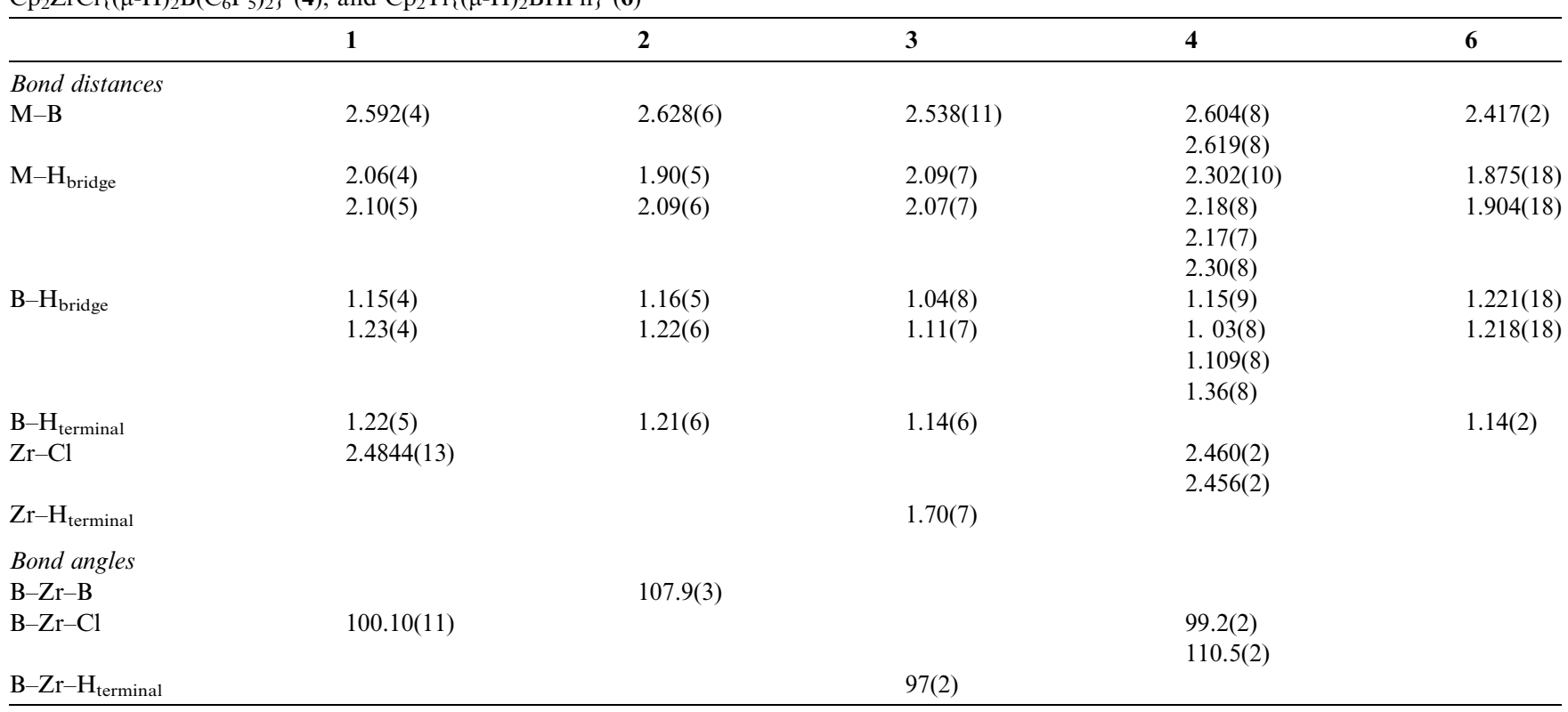




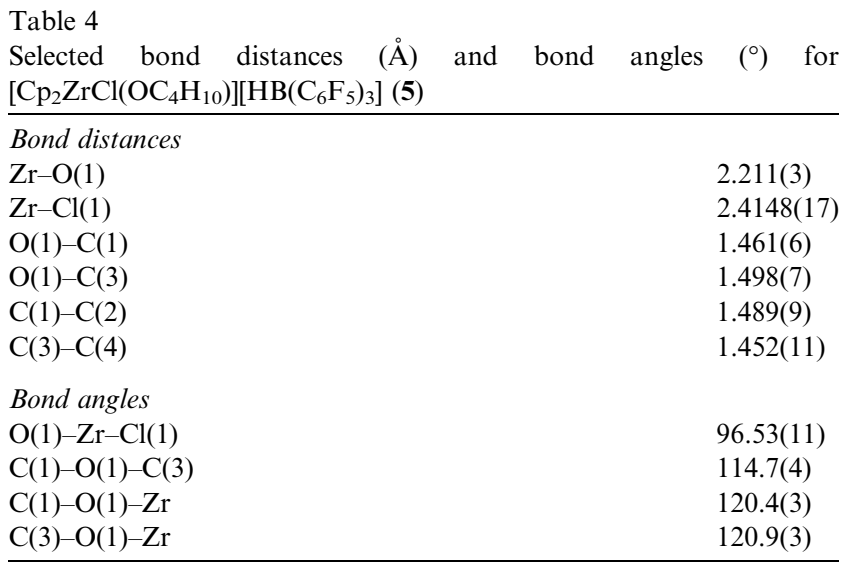

was applied to the data using the soRTAV [29] program. The structure was solved using the sHeLXs-97 [30] program and refined using SHELXL-97 [31] program by full-matrix least-squares on $F^{2}$ values. All non-hydrogen atoms, except for $\mathrm{C} 10-\mathrm{C} 19$ in compound 2, were refined with anisotropic thermal parameters. Hydrogen atoms attached to the zirconium and the boron atoms, and the carbon atoms $\mathrm{C} 10-\mathrm{C} 19$ in compound $\mathbf{2}$ were located from the difference Fourier map and were refined isotropically. Hydrogen atoms attached to the carbons were fixed at calculated positions and refined using a riding mode. Detailed crystal data are listed in Tables 1 and 2.

\subsection{Preparation of complexes}

\subsection{1. $\mathrm{Cp}_{2} \mathrm{ZrCl}\left\{(\mu-\mathrm{H})_{2} \mathrm{BHPh}\right\}$ (1)}

$\mathrm{Cp}_{2} \mathrm{ZrCl}_{2}(438 \mathrm{mg}, 1.50 \mathrm{mmol})$ and $\mathrm{LiBH}_{3} \mathrm{Ph}(152$ $\mathrm{mg}, 1.55 \mathrm{mmol}$ ) were charged to a flask in the drybox. The flask was evacuated and $20 \mathrm{ml}$ of the diethyl ether was condensed to the flask at $-78{ }^{\circ} \mathrm{C}$. The system was warmed to room temperature and stirred overnight. The $\mathrm{LiCl}$ formed was separated from the solution through filtration. A white solid was obtained after removal of the solvent from the filtrate. Colorless crystals of 1 ( $438 \mathrm{mg}, 84 \%$ yield) were obtained after crystallization in $\mathrm{Et}_{2} \mathrm{O}$ at $-35{ }^{\circ} \mathrm{C}$. ${ }^{11} \mathrm{~B}$ NMR $\left(\mathrm{d}_{8}-\right.$ THF): $\delta 2.37 \mathrm{ppm}\left(\mathrm{q}, J_{\mathrm{B}-\mathrm{H}}=76 \mathrm{~Hz}\right) .{ }^{1} \mathrm{H}$ NMR $\left(\mathrm{d}_{8^{-}}\right.$ THF): $\delta$ 7.27-6.29 (m, 5H, Ph), $6.32(\mathrm{~s}, 10 \mathrm{H}, \mathrm{Cp})$, and $1.00 \mathrm{ppm}$ (br, $\left.3 \mathrm{H}, \mathrm{BH}_{3}\right)$. $\mathrm{IR}(\mathrm{KBr}): 3110(\mathrm{~m})$, 3087(vw), 3065(vw), 3050(vw), 3011(vw), 2953(vw), 2924(vw), 2855(vw), 2692(vw), 2400(w), 2366(w), 2348(vw), 2271(vw), 2185(vw), 2087(m), 1992(w), 1936(vw), 1439(m), 1436(m), 1345(s), 1305(m), 1279(m), 1263(m), 1185(w), 1156(vw), 1126(vw), 1092(m), 1070(w), 1014(m), 926(vw), $\quad 826(\mathrm{vs})$, 770(vw), 720(s), 700(m), 671(vw), 651(vw), 610(vw), 581(vw), 548(vw), and 471(vw) $\mathrm{cm}^{-1}$. Anal. Calc. for $\mathrm{C}_{16} \mathrm{H}_{18} \mathrm{BClZr}$ : C, 55.25; H, 5.22. Found: C, 55.52; $\mathrm{H}, 5.14 \%$.

\subsection{2. $\mathrm{Cp}_{2} \mathrm{Zr}\left\{(\mu-\mathrm{H})_{2} \mathrm{BHPh}\right\}_{2} \cdot(1 / 2$ toluene) (2)}

In the drybox, $407 \mathrm{mg}(4.2 \mathrm{mmol})$ of $\mathrm{LiBH}_{3} \mathrm{Ph}$ and $584.7 \mathrm{mg}(2.0 \mathrm{mmol})$ of $\mathrm{Cp}_{2} \mathrm{ZrCl}_{2}$ were charged into a flask. The flask was evacuated, and $20 \mathrm{ml}$ of toluene was condensed to the flask at $-78{ }^{\circ} \mathrm{C}$. The system was warmed to room temperature over a $1 \mathrm{~h}$ period and stirred for additional $10 \mathrm{~h}$. The $\mathrm{LiCl}$ was separated from the solution through filtration and the solvent was reduced to about $10 \mathrm{ml}$. The toluene solution was kept at -35 ${ }^{\circ} \mathrm{C}$ for crystallization. A $776 \mathrm{mg}(86.3 \%$ yield $)$ of colorless product was isolated. ${ }^{11} \mathrm{~B}$ NMR $\left(\mathrm{C}_{6} \mathrm{H}_{6}\right): \delta-6.0 \mathrm{ppm}(\mathrm{q}$, $\left.J_{\mathrm{B}-\mathrm{H}}=70 \mathrm{~Hz}\right) .{ }^{1} \mathrm{H}$ NMR $\left(\mathrm{C}_{6} \mathrm{D}_{6}\right): \delta 7.65-7.27(\mathrm{~m}, 10 \mathrm{H}$, $\mathrm{Ph}$ ), 7.17-6.95 (m, Ph, toluene), 5.51 (s, 10H, Cp), 2.07 (s, $\mathrm{CH}_{3}$, toluene), and $1.39 \mathrm{ppm}\left(\mathrm{br}, 6 \mathrm{H}, \mathrm{BH}_{3}\right)$. $\mathrm{IR}(\mathrm{KBr})$ : 3140(vw), 3103(w), 3084(vw), 3060(w), 2997(w), $2375(\mathrm{~m}), \quad 2345(\mathrm{w}), \quad 2256(\mathrm{vw}), \quad 2172(\mathrm{w}), \quad 2094(\mathrm{~m})$, 1484(vw), 1460(vw), 1438(w), 1342(m), 1253(s), 1175(w), 1124(vw), 1085(m), 1023(m), 929(vw), 848(w), 824(vs), 766(vw), 728(s), 701(m), 671(w), 537(vw), and 464(vw) $\mathrm{cm}^{-1}$. Anal. Calc. for $\mathrm{C}_{25.5} \mathrm{H}_{30} \mathrm{~B}_{2} \mathrm{Zr}$ : C, 68.16; H, 6.73. Found: C, 67.82; H, 6.65\%.

\subsection{3. $\mathrm{Cp}{ }_{2} \mathrm{ZrH}\left\{(\mu-\mathrm{H})_{2} \mathrm{BHPh}\right\}$ (3)}

Method 1. In the drybox, $899 \mathrm{mg}(2.0 \mathrm{mmol})$ of $\mathrm{Cp}_{2} \mathrm{Zr}\left\{(\mu-\mathrm{H})_{2} \mathrm{BHPh}\right\}_{2} \cdot(1 / 2$ toluene $)$ was charged into a flask. The flask was evacuated, and $20 \mathrm{ml}$ of toluene was condensed to the flask at $-78{ }^{\circ} \mathrm{C}$. A $0.28 \mathrm{ml}(2.0$ mmol) of $\mathrm{N}\left(\mathrm{C}_{2} \mathrm{H}_{5}\right)_{3}$ was measured and transferred to the flask at $-78{ }^{\circ} \mathrm{C}$. The flask was warmed to room temperature and continued to stir for $4 \mathrm{~h}$. The cloudy solution turned clear after stirring at room temperature for few minutes. After the reaction the toluene was removed and the resulting white solid was dissolved in the diethyl ether and kept at $-35^{\circ} \mathrm{C}$ for crystallization. Both compounds, $\mathrm{Cp}_{2} \mathrm{ZrH}\left\{(\mu-\mathrm{H})_{2} \mathrm{BHPh}\right\}$ and $\left(\mathrm{C}_{2} \mathrm{H}_{5}\right)_{3} \mathrm{~N} \cdot \mathrm{BH}_{2} \mathrm{Ph}$, were crystallized and they were isolated through manual separation and repeated recrystallization. A $455 \mathrm{mg}$ (72.6\% yield) of $\mathrm{Cp}_{2} \mathrm{ZrH}\left\{(\mu-\mathrm{H})_{2} \mathrm{BHPh}\right\}$ and a $289 \mathrm{mg}$ (75.6\% yield) of $\left(\mathrm{C}_{2} \mathrm{H}_{5}\right)_{3} \mathrm{~N} \cdot \mathrm{BH}_{2} \mathrm{Ph}$ were obtained.

Method 2. A $234.9 \mathrm{mg}(2.4 \mathrm{mmol})$ of $\mathrm{LiBH}_{3} \mathrm{Ph}$ and $515 \mathrm{mg}(2.0 \mathrm{mmol})$ of $\mathrm{Cp}_{2} \mathrm{ZrHCl}$ were charged to a flask covered with aluminum foil. The flask was evacuated and about $20 \mathrm{ml}$ of toluene was condensed into the flask at $-78{ }^{\circ} \mathrm{C}$. The system was warmed to room temperature and stirred overnight. The $\mathrm{LiCl}$ was removed through filtration and an oily species was obtained after removal of the solvent under vacuum. The oily species was allowed to stand at room temperature for days and a $60 \mathrm{mg}(9.6 \%$ yield $)$ of colorless crystals was obtained. Analysis data for $\mathrm{Cp}_{2} \mathrm{ZrH}\left\{(\mu-\mathrm{H})_{2} \mathrm{BHPh}\right\}:{ }^{11} \mathrm{~B}$ NMR (toluene): $\delta 17.40 \mathrm{ppm}\left(\mathrm{q}, J_{\mathrm{B}-\mathrm{H}}=75 \mathrm{~Hz}\right) .{ }^{1} \mathrm{H}$ NMR $\left(\mathrm{C}_{6} \mathrm{D}_{6}\right): \delta 7.48-7.10(\mathrm{~m}, 5 \mathrm{H}, \mathrm{Ph}), 5.53(\mathrm{~s}, 10 \mathrm{H}$, $\mathrm{Cp}), 4.48$ (s, $1 \mathrm{H}, \mathrm{ZrH})$, and $-0.42 \mathrm{ppm}\left(\mathrm{br}, 3 \mathrm{H}, \mathrm{BH}_{3}\right)$. IR(KBr): 3102(w), 3063(w), 3003(w), 2964(w), 2774(vw), 2394(m), 2346(w), 2265(vw), 2173(vw), 2033(w), 2008(w), 1962(m), 1924(m), $\quad 1920(\mathrm{~m})$, 
1912(m), 1597(br, m), 1432(m), 1420(m), 1396(s), 1389(s), 1261(m), 1181(m), 1088(s), 1066(m), 1028(m), 1014(s), 915(vw), 812(vs), 716(s), 698(m), 653(w), 583(w), and 458(vw) $\mathrm{cm}^{-1}$. Anal. Calc. for $\mathrm{C}_{16} \mathrm{H}_{19} \mathrm{BZr}$ : C, 61.33; H, 6.11. Found: C, 61.42; H, 6.06\%. Analysis data for $\left(\mathrm{C}_{2} \mathrm{H}_{5}\right)_{3} \mathrm{~N} \cdot \mathrm{BH}_{2} \mathrm{Ph}:{ }^{11} \mathrm{~B}$ NMR (toluene): $\delta$ $-6.78 \mathrm{ppm}\left(\mathrm{t}, J_{\mathrm{B}-\mathrm{H}}=97 \mathrm{~Hz}\right) .{ }^{1} \mathrm{H}$ NMR $\left(\mathrm{C}_{6} \mathrm{D}_{6}\right): \delta$ 7.81-7.29 (m, 5H, Ph), $2.86\left(\mathrm{br}, \mathrm{q}, 2 \mathrm{H}, \mathrm{BH}_{2}\right), 2.22(\mathrm{q}$, $\left.6 \mathrm{H}, \mathrm{CH}_{2}, J_{\mathrm{H}-\mathrm{H}}=7.3 \mathrm{~Hz}\right)$, and $0.74 \mathrm{ppm}\left(\mathrm{t}, 9 \mathrm{H}, \mathrm{CH}_{3}\right.$, $\left.J_{\mathrm{H}-\mathrm{H}}=7.3 \mathrm{~Hz}\right) . \operatorname{IR}(\mathrm{KBr}): 3080(\mathrm{vw}), 3064(\mathrm{w}), 3045(\mathrm{w})$, 2999(s), 2976(m), 2943(w), 2912(w), 2877(w), 2816(vw), 2418(w), 2349(br, vs), 2295(m), 2276(w), 2256(w), 2210(vw), 2191(vw), 2092(vw), 1560(vw), 1475(m), $1460(\mathrm{~m}), \quad 1452(\mathrm{~m}), \quad 1444(\mathrm{w}), \quad 1429(\mathrm{w}), \quad 1414(\mathrm{vw})$, 1381(s), 1356(w), 1340(vw), 1261(vw), 1198(s), 1173(m), 1151(s), 1126(w), 1107(s), 1088(m), 1068(w), 1055(w), 1034(m), 1011(m), 993(w), 904(vw), 889(vw), 854(vw), 823(vw), 800(vw), 776(m), 760(m), 737(s), 708(s), 638(m), and 449(vw) $\mathrm{cm}^{-1}$. Anal. Calc. for $\mathrm{C}_{12} \mathrm{H}_{22} \mathrm{BN}$ : C, 75.41; H, 11.60; N, 7.33. Found: C, $75.05 ; \mathrm{H}, 11.50 ; \mathrm{N}, 7.30 \%$.

\subsubsection{Reaction of $\mathrm{Cp}_{2} \mathrm{ZrCl}\left\{(\mu-H)_{2} \mathrm{BHPh}\right\}$ with $\mathrm{B}\left(\mathrm{C}_{6} F_{5}\right)_{3}$ in toluene}

In the drybox, $347.8 \mathrm{mg}(1.00 \mathrm{mmol})$ of $\mathrm{Cp}_{2} \mathrm{ZrCl}\{(\mu-$ $\left.\mathrm{H})_{2} \mathrm{BHPh}\right\}$ and $342.0 \mathrm{mg}(0.67 \mathrm{mmol})$ of $\mathrm{B}\left(\mathrm{C}_{6} \mathrm{~F}_{5}\right)_{3}$ were charged into a $50 \mathrm{ml}$ flask. The flask was evacuated and $20 \mathrm{ml}$ of the toluene was condensed to the flask at -78 ${ }^{\circ} \mathrm{C}$. The flask was warmed to room temperature and continued to stir overnight. The solution was separated from the solids through filtration and the solids were washed with two portions of $20 \mathrm{ml}$ of toluene. The solution were combined and white solids were obtained after removal of the volatile species. Several crystals of $\mathrm{Cp}_{2} \mathrm{ZrCl}\left\{(\mu-\mathrm{H})_{2} \mathrm{~B}\left(\mathrm{C}_{6} \mathrm{~F}_{5}\right)_{2}\right\}$ were obtained from a hexane/toluene mixed solvent system. ${ }^{11} \mathrm{~B}$ NMR (toluene): $\delta-10.6 \mathrm{ppm}\left(\mathrm{t}, J_{\mathrm{B}-\mathrm{H}}=67 \mathrm{~Hz}\right) .{ }^{1} \mathrm{H}$ NMR $\left(\mathrm{C}_{6} \mathrm{D}_{6}\right): \delta$ $5.63(\mathrm{~s}, 10 \mathrm{H}, \mathrm{Cp})$ and $0.38 \mathrm{ppm}\left(\mathrm{br}, \mathrm{q}, 2 \mathrm{H}, \mathrm{BH}_{2}\right)$.

\subsection{5. $\left[\mathrm{Cp}_{2} \mathrm{ZrCl}\left(\mathrm{OC}_{4} \mathrm{H}_{10}\right)\right]\left[\mathrm{HB}\left(\mathrm{C}_{6} F_{5}\right)_{3}\right]$ (5)}

$\mathrm{Cp}_{2} \mathrm{ZrCl}\left\{(\mu-\mathrm{H})_{2} \mathrm{BHPh}\right\},(347.8 \mathrm{mg}, 1.0 \mathrm{mmol})$ and $\mathrm{B}\left(\mathrm{C}_{6} \mathrm{~F}_{5}\right)_{3}(512.0 \mathrm{mg}, 1.0 \mathrm{mmol})$ were charged into a flask in the drybox. The flask was evacuated and $15 \mathrm{ml}$ of diethyl ether was condensed to the flask at $-78{ }^{\circ} \mathrm{C}$. The system was warmed to room temperature gradually and stop stirring after a clear solution was formed. Pale yellow-green crystals were grown gradually. After standing at room temperature for $10 \mathrm{~h}$, the crystals of $\left[\mathrm{Cp}_{2} \mathrm{ZrCl}\left(\mathrm{OC}_{4} \mathrm{H}_{10}\right)\right]\left[\mathrm{HB}\left(\mathrm{C}_{6} \mathrm{~F}_{5}\right)_{3}\right]$ were separated from the solution through filtration. These crystals were washed with two portions of $10 \mathrm{ml}$ ether and were dried under vacuum. A $674.0 \mathrm{mg}$ (79.9\% yield) of pale yellowgreen crystals was obtained. ${ }^{11} \mathrm{~B}$ NMR (THF): $\delta-25.9$ ppm (q, $\left.J_{\mathrm{B}-\mathrm{H}}=93 \mathrm{~Hz}\right) .{ }^{1} \mathrm{H}$ NMR $\left(\mathrm{d}_{8}\right.$-THF): $\delta 6.85(\mathrm{~s}$, $10 \mathrm{H}, \mathrm{Cp}$ ), 3.80 (br, q, $1 \mathrm{H}, \mathrm{BH}$ ), 3.38 (q. $2 \mathrm{H}, \mathrm{CH}_{2}$ ), $1.11 \mathrm{ppm}\left(\mathrm{t}, 3 \mathrm{H}, \mathrm{CH}_{3}\right)$. IR( $\left.\mathrm{KBr}\right): 3123(\mathrm{~m}), 3095(\mathrm{w})$, 3001(w), 2987(w), 2947(vw), 2908(vw), 2873(vw), 2366(br, m), 2339(w), 2027(vw), 1863(vw), 1776(vw), 1639(s), 1601(w), 1550(w), 1512(s), 1460(br, vs), 1390(m), 1375(m), 1321(w), 1273(s), 1184(w), 1115(s), 1101(s), 1072(s), 1014(m), 970(vs), 906(m), 879(w), 825(s), 754(s), 723(m), 685(vw), 654(m), 602(w), 563(w), 521(w), 469(vw), and 409(vw) $\mathrm{cm}^{-1}$ Anal. Calc. for $\mathrm{C}_{32} \mathrm{H}_{21} \mathrm{BClF}_{15} \mathrm{OZr}$ : C, 45.54; $\mathrm{H}, 2.51$. Found: $\mathrm{C}$, 45.60; H, $2.49 \%$.

\subsection{6. $C p_{2} T i\left\{(\mu-H){ }_{2} B H P h\right\}$ (6)}

In the drybox, $470 \mathrm{mg}(4.8 \mathrm{mmol})$ of $\mathrm{LiBH}_{3} \mathrm{Ph}$ and $500 \mathrm{mg}(2.0 \mathrm{mmol})$ of $\mathrm{Cp}_{2} \mathrm{TiCl}_{2}$ were charged to a flask. The flask was evacuated and about $20 \mathrm{ml}$ of diethyl ether was condensed to the flask at $-78^{\circ} \mathrm{C}$. The system was warmed to room temperature and stirred for $6 \mathrm{~h}$. During the reaction, $\mathrm{H}_{2}$ gas evolved and the solution became purple in color. The $\mathrm{LiCl}$ was removed by filtration and the volatile materials were removed under vacuum. The purple solid left in the flask was dissolved in $\mathrm{Et}_{2} \mathrm{O}$ and kept at $-35^{\circ} \mathrm{C}$ for crystallization. A $518 \mathrm{mg}$ $\left(96.3 \%\right.$ yield) of purple crystals were obtained. ${ }^{11} \mathrm{~B}$ NMR ( $\mathrm{d}_{8}$-THF): not observed. ${ }^{1} \mathrm{H}$ NMR $\left(\mathrm{d}_{8}\right.$-THF): $\delta$ 7.68(br, s), 6.89(s), and 6.55(s) ppm. IR(KBr): 3117(vw), 3091(vw), 3066(w), 3045(vw), 2999(w), 2969(vw), 2928(vw), 2029(vw), 2003(w), 1911(m), 1896(m), 1820(w), 1804(w), 1431(m), 1389(vs), 1365(m), 1343(w), 1309(w), 1263(w), 1176(w), 1156(w), 1120(w), 1064(w), 1015(s), 997(w), 916(vw), 906(vw), 819(m), 804(vs), 779(w), 739(m), 710(s), 666(vw), 604(w), 558(w), 487(vw), and 436(vw) $\mathrm{cm}^{-1}$. Anal. Calc. for $\mathrm{C}_{16} \mathrm{H}_{18} \mathrm{BTi}$ : $\mathrm{C}, 71.44 ; \mathrm{H}, 7.74$. Found: $\mathrm{C}, 71.66$; $\mathrm{H}$, $7.63 \%$

\section{Acknowledgement}

This work was supported by the National Science Council of the ROC through Grant NSC 92-2113-M259-007.

\section{Appendix A. Supplementary material}

Crystallographic data for the structural analysis have been deposited with the Cambridge Crystallographic Data Center, CCDC Nos. 238550 (compound 1), 238551 (compound 2), 238552 (compound 3), 238553 (compound 4), 238554 (compound 5), 238555 (compound 6), Copies of this information may be obtained free of charge from The Director, CCDC, 12 Union Road, Cambridge CB2 1EZ, UK (fax: +44 1223 336033; e-mail: deposit@ccdc.cam.ac.uk or www: http://www.ccdc.cam.ac.uk). Supplementary data associated with this article can be found, in the online version at doi:10.1016/j.jorganchem.2004.09.026. 


\section{References}

[1] (a) T.J. Marks, J.R. Kolb, Chem. Rev. 77 (1977) 263; (b) K.B. Gilbert, S.K. Boocock, S.G. Shore, Compounds with bonds between a transition metal and boron, in: G. Wilkinson, F.G.A. Stone, E.W. Abel (Eds.), Comprehensive Organometallic Chemistry, Pergamon Press Inc., New York, 1982, pp. 879-945; (c) L. Barton, D.K. Srivastava, Metallaboranes, in: G. Wilkinson, E.W. Abel, F.G.A. Stone (Eds.), Comprehensive Organometallic Chemistry, Pergamon Press Inc., New York, 1995, pp. 275-372;

(d) M. Ephritikhine, Chem. Rev. 97 (1997) 2193.

[2] (a) F.-C. Liu, K.-Y. Chen, J.-H. Chen, G.-H. Lee, S.-M. Peng, Inorg. Chem. 42 (2003) 1758;

(b) W.K. Kot, N.M. Edelstein, A. Zalkin, Inorg. Chem. 26 (1987) 1339;

(c) R. Shinomoto, E. Gamp, N.M. Edelstein, D.H. Templeton, A. Zalkin, Inorg. Chem. 22 (1983) 2351;

(d) R. Shinomoto, A. Zalkin, N.M. Edelstein, Inorg. Chem. Acta 139 (1987) 97;

(e) J. Brennan, R. Shinomoto, A. Zalkin, N.M. Edelstein, Inorg. Chem. 23 (1984) 4143;

(f) R. Shinomoto, A. Zalkin, N.M. Edelstein, D. Zhang, Inorg. Chem. 26 (1987) 2868;

(g) R. Shinomoto, J. Brennan, N.M. Edelstein, A. Zalkin, Inorg. Chem. 24 (1985) 2896.

[3] (a) J.C. Bommer, K.W. Morse, Inorg. Chem. 22 (1983) 592;

(b) J.C. Bommer, K.W. Morse, Inorg. Chem. 18 (1979) 531;

(c) J.C. Bommer, K.W. Morse, Inorg. Chem. 19 (1980) 587.

[4] (a) D.G. Holah, A.N. Hughes, N.I. Khan, Can. J. Chem. 62 (1984) 1016;

(b) B.G. Segal, S.J. Lippard, Inorg. Chem. 16 (1977) 1623;

(c) K.M. Melmed, T.-I. Li, J.J. Mayerle, S.J. Lippard, J. Am. Chem. Soc. 96 (1974) 69;

(d) R. Hedelt, C. Schulzke, D. Rehder, Inorg. Chem. Commun. 3 (2000) 300.

[5] P. Paetzold, L. Geret, R. Boese, J. Organomet. Chem. 381 (1990) 1.

[6] (a) R.K. Nanda, M.G.H. Wallbridge, Inorg. Chem. 3 (1964) 1798;

(b) B.D. James, R.K. Nanda, M.G.H. Wallbridge, Inorg. Chem. 6 (1967) 1979.

[7] F.-C. Liu, J. Liu, E.A. Meyers, S.G. Shore, Inorg. Chem. 37 (1998) 3293.

[8] The closest non-bonded contact distance of the phenyl group with other atoms is $3.405 \AA$ in $\mathrm{C}(1 \mathrm{~A})-(13)$.

[9] R.E. von H. Spence, W.E. Piers, Y. Sun, M. Parvez, L.R. MacGillivray, M.J. Zaworotko, Organometallics 17 (1998) 2459.

[10] J. Liu, E.A. Meyers, S.G. Shore, Inorg. Chem. 37 (1998) 496.
[11] (a) B. Singaram, T.E. Cole, H.C. Brown, Organometallics 3 (1984) 774

(b) W. Biffar, H. Nöth, D. Sedlak, Organometallics 2 (1983) 579.

[12] F.-C. Liu, B. Du, J. Liu, E.A. Meyers, S.G. Shore, Inorg. Chem. 38 (1999) 3228.

[13] P.T. Wolczanski, J.E. Bercaw, Organometallics 1 (1982) 793.

[14] R.E. von H. Spence, D.J. Parks, W.E. Piers, M.-A. MacDonald, M.J. Zaworotko, S.J. Rettig, Angew. Chem., Int. Ed. Engl. 34 (1995) 1230.

[15] F.-C. Liu, J. Liu, E.A. Meyers, S.G. Shore, J. Am. Chem. Soc. $122(2000) 6106$.

[16] F.-C. Liu, C.E. Plečnik, S. Liu, J. Liu, E.A. Meyers, S.G. Shore, J. Organomet. Chem. 627 (2001) 109.

[17] J.W. Lauher, R. Hoffmann, J. Am. Chem. Soc. 98 (1976) 1729.

[18] B. Sztáray, E. Rosta, Z. Böcskey, L. Szepes, J. Organomet. Chem. 582 (1999) 267.

[19] P.L. Johnson, S.A. Cohen, T.J. Marks, J.M. Williams, J. Am. Chem. Soc. 100 (1978) 2709.

[20] The B-Zr-B angles of other metallocene hydroborate disubstituted compounds were not reported.

[21] R.W. Broach, I.-S. Chuang, T.J. Marks, J.M. Williams, Inorg. Chem. 22 (1983) 1081.

[22] (a) G.T. Jordan IV, S.G. Shore, Inorg. Chem. 35 (1996) 1087; (b) G.T. Jordan IV, F.-C. Liu, S. Shore, J. Inorg. Chem. 36 (1997) 5597.

[23] W.J. Highcock, R.M. Mills, J.L. Spencer, P. Woodward, J. Chem. Soc., Dalton Trans. (1986) 821.

[24] S.B. Stones, J.L. Peterson, Inorg. Chem. 20 (1981) 2889.

[25] M.B. Fischer, E.J. James, T.J. McNeese, S.C. Nyburg, B. Posin, W. Wong-Ng, S.S. Wreford, J. Am. Chem. Soc. 102 (1980) 4941.

[26] (a) W.A. Howard, G. Parkin, J. Am. Chem. Soc. 116 (1994) 606; (b) W.A. Howard, M. Waters, G. Parkin, J. Am. Chem. Soc. 115 (1993) 4917.

[27] (a) K.M. Melmed, D. Coucouvanis, S.J. Lippard, Inorg. Chem. 12 (1973) 232;

(b) G.I. Mamaeva, I. Hargittai, V.P. Spiridonov, Inorg. Chim. Acta 25 (1977) L123.

[28] Denzo-smn Z. Otwinowsky, W. Minor, Processing of X-ray diffraction data collected in oscillation mode, in: C.W. CarterJr., R.M. Sweet (Eds.), Methods in Enzymology, vol. 276: Macromolecular Crystllography, Part A, Academic Press, New York, 1997, pp. 307-326.

[29] (a) R.H. Blessing, Acta Crystallogr. Sect. A 51 (1995) 33; (b) R.H. Blessing, J. Appl. Crystallogr. 30 (1997) 421-426.

[30] SHElXs-97 G.M. Sheldrick, Acta Crystallogr., Sect. A 46 (1990) 467.

[31] G.M. Sheldrick, shelXL-97, University of Göttingen: Göttingen, Germany, 1997. 